\title{
ABORSI DAN RESIKONYA BAGI PEREMPUAN \\ (Dalam Pandangan Hukum Islam)
}

\begin{abstract}
Moh. Saifullah*
Abstrak

Membicarakan aborsi sebenarnya membicarakan perempuan. Hal ini dapat dibenarkan karena perempuan dipandang sebagai pelaku aborsi, yang secara faktual ini benar-benar terjadi dan ada di masyarakat. Aborsi yang dilakukan oleh perempuan sebenarnya beresiko tinggi terhadap kesehatan dan keselamatan jiwanya, namun tetap menjadi pilihan mereka dengan alasan aborsi merupakan hak reproduksi atau bentuk otonomi perempuan atas tubuhnya.

Dalam pandangan hukum Islam aborsi hukumnya haram. Seluruh ulama sepakat bahwa aborsi setelah kehamilan melewati masa 120 hari adalah haram, karena pada saat itu janin telah bernyawa. Boleh dilakukan jika kondisi "dharurat", seperti apabila membahayakan jiwa si ibu. Sedangkan aborsi pada usia kehamilan di bawah 40 hari hukumnya makruh. Inipun dengan syarat adanya keridhaan dari suami dan istri serta adanya rekomendasi dari dua orang dokter spesialis bahwa aborsi itu tidak menyebabkan kemudharatan bagi si ibu. Namun penulis sependapat dengan Imam Ghozali yang menyatakan bahwa aborsi adalah tindakan pidana yang haram tanpa melihat apakah sudah ada ruh atau belum, dengan argumen bahwa kehidupan telah dimulai sejak pertemuan antara air sperma dengan ovum di dalam rahim perempuan.
\end{abstract}

Kata Kunci: Aborsi, hukum Islam, haram, makruh

Membicarakan aborsi sebenarnya membicarakan perempuan. Membahas aborsi berarti membahas persoalan kehidupan perempuan. Hal ini dapat dibenarkan karena perempuan dipandang sebagai pelaku aborsi, yang secara faktual ini benarbenar terjadi dan ada di masyarakat. Faktanya, tidak kurang dari 2 juta perempuan Indonesia setiap tahun melakukan aborsi karena Kehamilan yang Tidak Diinginkan (KTD). Hasil penelitian oleh Pusat Kesehatan UI dan Yayasan Kesehatan Perempuan tahun 2003, ditemukan bahwa 77\% mereka yang melakukan aborsi adalah ibu rumah tangga yang memiliki suami dan hanya $12 \%$ dilakukan oleh remaja putri pra nikah. Ditemukan pula bahwa dari 2 juta kasus pertahun itu, kebanyakan melakukan aborsi yang tidak aman. Selain itu, di ASEAN, Indonesia merupakan yang tertinggi dalam angka kematian ibu. Dalam situs mengenai aborsi, ditulis bahwa setiap tahunnya 42 juta perempuan di dunia melakukan aborsi dan

\footnotetext{
${ }^{*}$ Dosen UPM Soshum ITS
}

jsh Jurnal Sosial Humaniora, Vol 4 No.1, Juni 2011 
setiap 10 menit seorang perempuan meninggal dunia secara sia-sia karena melakukan aborsi yang tidak aman (www.womenonweb.org)

Dari fakta tersebut dapatlah dijelaskan bahwa ternyata banyak perempuan yang melakukan aborsi, yang secara sadar atau tidak sebenarnya beresiko tinggi terhadap kesehatan dan keselamatan jiwanya sendiri dan anak yang dikandungnya. Karena itu perempuan harus banyak diberikan pengetahuan dan pemahaman tentang dampak negatif aborsi sekaligus diberikan pencerahan spiritual agar tidak dengan mudah melalukannya tindakan aborsi tersebut apapun alasannya, walaupun sebenarnya hal itu merupakan hak reproduksi atau bentuk otonomi perempuan atas tubuhnya.

Mengingat sangat luasnya permasalahan aborsi, maka penulis membatasi pembahasan aborsi hanya sekitar definisi dan macam aborsi, fakta dan alasan aborsi, resiko aborsi, dan tentang Hukum aborsi dalam dalam Pandangan Islam, tentunya sesuai dengan kemampuan penulis. Dengan harapan semoga dapat memberikan khazanah keilmuan semakin mendalam dan dapat memberikan manfaat sekaligus pencerahan bagi semua pihak, khususnya para wanita.

\section{Definisi dan Macam Aborsi}

Kata aborsi berasal dari bahasa Inggris yaitu abortion dan bahasa Latin abortus. secara etimologis berarti, gugur kandungan atau keguguran (M. Ali Hasan, 1998). Aborsi dalam bahasa arab disebut ijhadh yang berarti menjatuhkan, membuang, melempar atau menyingkirkan. Sedangkan dalam Kamus Besar Bahasa Indonesia aborsi adalah: 1). Terpancarnya embrio yang tidak mungkin lagi hidup (sebelum hasil bulan keempat dari kehamilan); keguguran atau keluron. 2). Keadaan terhentinya pertumbuhan yang normal (untuk makhluk hidup). 3). Guguran (janin).

Sardikin Ginaputra dari Fakultas Kedokteran UI, secara therminologi mendefinisikan aborsi sebagai pengakhiran kehamilan atau hasil konsepsi sebelum janin dapat hidup di luar kandungan. Sedangkan Maryono Reksodipura dari Fakultas Hukum UI mendefinisikan aborsi dengan pengeluaran hasil konsepsi dari rahim sebelum waktunya (sebelum dapat lahir secara alamiyah) (Masyfuk Zuhdi, 1989).

Dari berbagai definisi di atas, dapat disimpulkan bahwa aborsi adalah tindakan yang disengaja untuk menggugurkan kandungan yang belum cukup waktu 
untuk hidup atau pengguguran janin yang dikandung perempuan dengan tindakan tertentu sebelum sempurna masa kehamilannya, baik dalam keadaan hidup atau mati sebelum si janin bisa hidup di luar kandungan.

Dengan merujuk pada definisi yang terdapat dalam Kamus Besar Bahasa Indonesia, maka di dunia kedokteran dikenal tiga macam bentuk aborsi yakni:

1. Abortus Spontaneous (aborsi spontan atau aborsi alamiah) yakni aborsi yang terjadi dengan sendirinya, tidak disengaja dan tanpa pengaruh dari luar atau tanpa tindakan apapun. Aborsi spontan ini bisa terjadi disebabkan karena kurang baiknya kualitas sel telur dan sperma, atau bisa juga sebab lain seperti karena kecelakaan, penyakit syphilis, dan sebagainya.

2. Abortus Therapeuticus (aborsi medis), yakni aborsi yang dilakukan dengan pertimbangan medis yang sungguh-sungguh, matang dan tidak tergesa-gesa dan biasanya ini dilakukan umumnya untuk menyelamatkan jiwa si ibu.

3. Abortus Provocatus (aborsi buatan atau sengaja), aborsi yang dilakukan dengan sengaja dan sadar oleh si ibu maupun si pelaksana aborsi (dalam hal ini dokter, bidan atau dukun beranak) dan dilakukan tanpa indikasi medis apapun. Aborsi macam ini dianggap sebagai tindak pidana (Harkristutu Harkrisnowo, 2000).

Aborsi terakhir inilah yang sering disebut dengan aborsi illegal dan diancam hukuman, baik pidana maupun hukum Islam. Sedangkan untuk dua macam aborsi yang lain (abortus spontaneous dan abortus therapeuticus) hukum pidana dan hukum Islam memberikan kualifikasi dan ketentuan yang berbeda-beda menurut faktor penyebabnya, ringan dan beratnya serta jenis dan sifatnya.

\section{Fakta dan Alasan Aborsi}

Fakta yang terjadi di lapangan menunjukkan bahwa angka sebenarnya masih sulit dijadikan pedoman karena penelitian yang akurat terbentur kendala hukum dan norma-norma sosial. Namun yang pasti bahwa aborsi yang terjadi di tengah-tengah masyarakat dan angka-angka yang diperoleh belum menunjukkan jumlah kejadian yang sebenarnya.

Secara faktual, pada tahun 1994 diperkirakan terjadi 1.000.000 aborsi setiap tahun di Indonesia. 50\% diantaranya dilakukan oleh mereka yang belum menikah, dan dari jumlah ini kurang lebih 10-25\% adalah remaja. Tahun berikutnya, Bali 
setiap hari ada 100 remaja di Denpasar dan Badung yang ingin dipulihkan dari kehamilan yang tidak mereka inginkan (Andrian dkk, 1998).

Sedangkan angka yang disodorkan oleh Prof. Sudraji Sumapraja, dalam catatannya ia menyatakan $99,7 \%$ perempuan yang melakukan aborsi adalah ibu-ibu yang sudah menikah (Kompas, 30/11/1997). Sementara itu, penelitian lapangan yang dilakukan oleh Indraswari dari FISIP Unpad tahun 1997 menyimpulkan 85\% pelaku aborsi berstatus menikah. Penelitian ini juga mengungkapkan abortus spontan karena kelelahan, beban kerja berlebihan dan kondisi kesehatan mencapai angka 20\%. Selebihnya, $10 \%$ responden melakukan abortus provokatus terapikus (APT), dan 65\% responden melakukan abortus provokatus kriminalis (APK) (Syafiq Hasyim, 1999).

Fakta lain, tidak kurang dari 2 juta perempuan Indonesia setiap tahun melakukan aborsi karena Kehamilan yang Tidak Diinginkan (KTD). Hasil penelitian oleh Pusat Kesehatan UI dan Yayasan Kesehatan Perempuan tahun 2003, ditemukan bahwa 77\% mereka yang melakukan aborsi adalah ibu rumah tangga yang memiliki suami, hanya $12 \%$ oleh remaja putri. Kebanyakan aborsi yang dilakukan wanita Indonesia terindikasi aborsi yang tidak aman (Yendi Amalia, 2010).

Berdasarkan laporan WHO tahun 2006, angka ini meningkat menjadi 2,3 juta kasus per tahun. Diasumsikan terjadi 6.301 kasus setiap hari atau 4 kejadian setiap detiknya. Penelitian Yayasan Kesehatan Perempuan pada tahun 2006 menyebutkan $87 \%$ yang melakukan aborsi adalah istri dan ibu, sedangkan 15-20\% dilakukan remaja putri. Hal ini pula yang menjadikan tingginya angka kematian ibu di Indonesia, menjadikan Indonesia sebagai negara yang angka kematian ibunya tertinggi di seluruh Asia Tenggara (Majalah Gemari September 2001).

Dengan sangat fariatif angka-angka di atas, menunjukkan bahwa belum menggambarkan keadaan yang sesungguhnya. Hal ini disebabkan karena dalam penelitian responden yang dijadikan sampel tidak banyak dan tidak luas sebaran wilayahnya. Di samping itu responden juga kurang jujur dan tidak transparan dalam menjawab pertanyaan yang diajukan oleh peneliti karena ada anggapan bahwa aborsi merupakan tindakan kriminal atau aib pribadi yang harus dirahasiakan. 
Mengenai alasan wanita melakukan aborsi, ternyata berdasarkan data yang kami himpun sangat fariatif, tetapi alasan yang paling utama adalah alasan non medis. Di Amerika serikat alasan wanita melakukan aborsi antara lain dapat dilihat dari hasil penelitian berikut ini: 1). Tidak ingin memiliki anak karena khawatir mengganggu karier, sekolah atau tanggung jawab lainnya (75 \%). 2). Tidak memiliki cukup beaya untuk merawat dan menyekolahkan anak (66 \%). 3). Tidak ingin memiliki anak tanpa ayah (50\%). Alasan alasan seperti itu juga dibenarkan oleh para wanita Indonesia yang menyakinkan dirinya bahwa membunuh janin yang ada dalam kandungannya adalah boleh dan benar. Semua alasan tersebut sebenarnya tidak mendasar, sebaliknya alasan-alasan itu hanya menunjukkan ketidak pedulian seorang wanita dan hanya mementingkan dirinya sendiri.

Data ini juga didukung oleh Studi dari Aida Torres dan Jacqueline Sarroch Forrest (1998) yang menyatakan bahwa hanya $1 \%$ kasus aborsi disebabkan karena pemerkosaan, $3 \%$ karena membahayakan nyawa si Ibu, 3\% karena janin akan tumbuh cacat tubuh sesius, sedangkan $93 \%$ kasus aborsi disebabkan karena alasan yang sifatnya untuk kepentingan diri sendiri( www.genetik2000.com.).

Jika dilihat dari sudut pandang perbedaan aborsi yang dilakukan oleh perempuan yang sudah menikah dengan yang belum menikah maka dapat dikelompokkan alasan mereka melakukan aborsi sebagai berikut:

1. Pada perempuan yang belum/tidak menikah, alasan melakukan aborsi di antaranya karena masih berusia remaja, pacar tidak mau bertanggung jawab, takut pada orang tua, berstatus janda yang hamil di luar nikah, dan berstatus sebagai perempuan simpanan seseorang dan dilarang hamil oleh pasangannya.

2. Pada perempuan yang sudah menikah, alasannya antara lain karena kegagalan alat kontrasepsi, jarak kelahiran yang terlalu rapat, jumlah anak yang terlalu banyak, terlalu tua untuk melahirkan, faktor sosial ekonomi (tidak sanggup lagi membiayai anak-anaknya dan khawatir masa depan anak tidak terjamin), alasan medis, sedang dalam proses perceraian dengan suami, atau karena berstatus sebagai isteri kedua dan suaminya tidak menginginkan kehadiran anak dari dia (Atlas Hendartini Habsjah, 2001). 
Dari alasan-alasan yang dikemukakan, tampak bahwa sebagian besar aborsi bukan hanya disebabkan oleh kemauan murni perempuan. Ia melakukan aborsi karena takut dengan resiko sosial, takut kepada orang lain (suami atau orang tua dan keluarga), adanya paksaan dari keluarga, adanya kondisi keluarga yang membuatnya tidak berani punya anak lagi dan alasan lainnya.

\section{Resiko Aborsi bagi Wanita}

Telah dijelaskan sebelumnya bahwa Aborsi memiliki resiko yang tinggi terhadap kesehatan dan keselamatan seorang wanita bahkan bisa beresiko fatal berupa kematian. Tidak benar jika dikatakan bahwa seseorang yang melakukan aborsi tidak merasakan apa apa dan langsung boleh pulang. Ini adalah informasi yang salah dan sangat menyesatkan bagi setiap wanita, terutama mereka yang sedang kebingungan karena tidak menginginkan kehamilan yang sudah terjadi, sehingga mereka tanpa berfikir panjang untuk segera melakukan aborsi tanpa berfikir resikonya.

Dalam buku Facts of Life yang ditulis oleh Brian Clowes, Ph.d, dijelaskan bahwa pada saat dan setelah melakukan aborsi ada beberapa resiko yang akan dihadapi seorang wanita, yang secara garis besarnya terdapat dua macam resiko, yaitu:

1. Resiko kesehatan dan keselamatan secara fisik

Pada saat dan setelah melakukan aborsi, maka wanita ada kemungkinan besar mengalami resiko kesehatan dan keselamatan terhadap tubuh atau fisiknya diantaranya berupa :

a. Kematian mendadak karena pendarahan hebat,

b. Kematian mendadak karena pembiusan yang gagal,

c. Kematian secara lambat akibat infeksi serius disekitar kandungan,

d. Rahim yang sobek (uterine perforation),

e. Kerusakan leher rahim (carvical lacerations) yang akan menyebabkan cacat pada anak berikutnya,

f. Kanker payudara (karena ketidak seimbangan hormon estrogen pada wanita),

g. Kanker indung telur ( ovarian cancer) 
h. Kanker leher rahim (cervical cancer),

i. Kanker hati (Liver cancer),

j. Kelainan pada plasenta atau ari-ari yang akan menyebabkan cacat pada anak berikutnya dan pendarahan hebat pada saat kehamilan berikutnya,

k. Menjadi mandul atau tidak mampu memiliki keturunan lagi,

1. Infeksi rongga panggul,

m. Infeksi pada lapisan rahim.

2. Resiko gangguan psikologis atau kejiwaan

Proses aborsi bukan saja suatu proses yang memiliki resiko tinggi dari segi kesehatan dan keselamatan seorang wanita secara fisik, tetapi juga memiliki dampak yang sangat hebat terhadap mental atau kejiwaan seorang wanita. Gejala ini di kenal di dunia psikologi sebagai Post abortion syindrome (sindrom pasca aborsi) atau PAS. Gejala-gejala ini dicatat dalam Psychological Reactions Reported After Abortion yang diterbitkan oleh The Post Abortion Review (1994). Diantara gejala-gejala kejiwaan tersebut adalah sebagai berikut:
a. Kehilangan harga diri $(82 \%)$,
b. Teriak-teriak- histeris (51\%),
c. Mimpi buruk berkali-kali mengenai bayi (63\%),
d. Ingin melakukan bunuh diri (28\%),
e. Mulai menggunakan obat-obat terlarang (41\%),
f. Tidak bisa menikmati lagi hubungan seksual (59\%),

Disamping gejala tersebut di atas, para wanita yang melakukan aborsi akan dipenuhi atau dihantui perasaan bersalah yang tidak pernah hilang selama bertahun-tahun dalam hidupnya.

\section{Proses Kehidupan Janin dan Awal Kehidupan Manusia.}

Secara eksplisit al-Qur'an tidak menyatakan kapan janin atau embrio disebut sebagai "manusia". Namun demikian al-Qur'an banyak menjelaskan proses perkembangan janin dalam kandungan ibu. Ada yang dijelaskan secara sekilas, dan ada pula yang dijelaskan secara rinci. Ayat-ayat yang menjelaskan proses 
perkembangan janin secara rinci dijelaskan dalam Al Qur'an surat Al-Hajj : 5, yang artinya:

"Hai manusia, jika kamu dalam keraguan tentang kebangkitan (dari kubur), maka ketahuilah sesungguhnya Kami telah menjadikan kamu dari tanah, kemudian dari setetes mani, kemudian dari segumpal darah, kemudian dari segumpal daging yang sempurna kejadiannya dan yang tidak sempurna, agar Kami jelaskan kepada kamu dan Kami tetapkan dalam rahim, apa yang Kami kehendaki sampai waktu yang sudah ditentukan, kemudian Kami keluarkan kamu sebagai bayi ...”.

Juga dijelaskan dalam Al Qur'an surat All-Mu'minun : 12 - 14 yang artinya:

"Dan sesungguhnya Kami telah menciptakan manusia dari suatu saripati (berasal) dari tanah. (12) Kemudian Kami jadikan saripati itu air mani (yang disimpan) dalam tempat yang kokoh (rahim). (13) Kemudian air mani itu Kami jadikan segumpal darah, lalu segumpal darah itu Kami jadikan segumpal daging, dan segumpal daging daging itu Kami jadikan tulang belulang, lalu tulang belulang itu Kami bungkus dengan daging. Kemudian Kami jadikan dia makhluk yang (berbentuk) lain. Maha Suci Allah Pencipta Yang Paling Baik”. (14)

Dalam ayat-ayat di atas, secara rinci Allah SWT menjelaskan proses penciptaan manusia dan perkembangan janin. Ayat-ayat di atas menjelaskan bahwa pada awal kejadiannya manusia diciptakan dari tanah (Adam as), selanjutnya anak cucu Adam diciptakan dari "nuthfah" (air mani) yang mengandung beribu-ribu sperma yang tidak bisa dilihat dengan mata telanjang. Setelah salah satu sel itu bertemu dengan ovum lalu menyatu dan bergantung pada dinding rahim, selang beberapa waktu "nuthfah" itu berubah menjadi "alaqah" (segumpah darah). Selanjutnya ia akan berubah menjadi "mudghah" (segumpal daging). Kemudian Allah menciptakan tulang belulang dari "mudghah" itu dan membungkusnya dengan daging. Selang beberapa waktu, ia akan menjadi makhluk yang memiliki bentuk yang indah sampai dilahirkan ke dunia menjadi bayi.

Demikianlah, al-Qur'an menjelaskan tahapan-tahapan kejadian manusia di dalam rahim. Namun demikian ayat-ayat di atas tidak menyebut kapan janin mempunyai jiwa/ruh. Informasi mengenai hal ini terdapat dalam hadits Nabi. Paling tidak dua hadits Nabi yang mengungkap peniupan ruh ke dalam janin, yakni:

Pertama : HR. Bukhari dan Muslim dari Abdullah bin Mas'ud:

"Sesungguhnya kamu berada di rahim ibumu selama 40 hari sebagai nuthfah, kemudian menjadi 'alaqah selama masa yang sama, lalu menjadi 
mudghah pada masa yang sama pula. Lalu Allah mengutus seorang malaikat dan meniupkan ruh ke dalam tubuhnya. Malaikat itu kemudian diperintahkanNya menulis empat kalimat, lalu malaikat itu menulis rizkinya, ajalnya, amalnya, kebahagiaan dan kesengsaraannya...”.

Kedua : HR. Muslim dari Huzaifah bin Asid:

"Jika nuthfah melewati 42 malam, maka Tuhan mengutus malaikat untuk membentuk rupa, pendengaran, penglihatan, kulit, daging dan tulangnya. Malaikat bertanya, "Ya Tuhan, lelaki atau perempuan?" Allah pun memutuskan sesuai kehendakNya dan malaikat mencatatnya...".

Dari hadits-hadits di atas, ada dua informasi mengenai kapan ruh ditiupkan. Hadits pertama menyatakan ruh ditiupkan setelah embrio melewati masa 120 hari yang terdiri dari tiga tahap: 40 hari menjadi nuthfah, 40 hari menjadi 'alaqah dan 40 hari mejadi mudghah. Sedangkan hadits kedua mengatakan ruh ditiupkan setelah embrio melewati masa 42 hari. Riwayat lain ada yang menyebutkan 40 hari dan 45 hari.

Pemberian ruh kepada janin inilah yang kemudian menjadi sumber ikhtilaf mengenai hukum aborsi karena keberadaan ruh dianggap sebagian fuqaha sebagai tanda awal kehidupan manusia dalam arti yang sesungguhnya, yakni manusia yang memiliki raga dan jiwa. Akan tetapi pendapat yang kuat dari para fuqaha adalah hadits yang pertama, yaitu setelah janin berumur lebih dari 120 hari atau 4 bulan lebih yang kemudian dianggap sebagai awal kehidupan manusia.

\section{Hukum Aborsi dalam Pandangan Islam}

Sebagai konsekuensi dari pemahaman ayat dan hadits sebagaimana dijelaskan di atas, para fuqaha membuat formulasi hukum yang berbeda-beda mengenai aborsi. Perlu untuk dikemukakan di sini, para fuqaha (klasik) memberlakukan hukum ini secara umum, yakni mencakup aborsi di dalam dan di luar perkawinan (kehamilan karena seks di luar nikah). Hanya saja, perkembangan terakhir menunjukkan adanya formulasi hukum tersendiri bagi aborsi yang disebabkan oleh hamil di luar nikah dengan alasan-alasan yang tidak semata-mata bersifat fiqhi, melainkan juga menyertakan alasan-alasan yang sifatnya moral dan sosial. 
Seluruh ulama dari semua madzhab sepakat bahwa aborsi setelah kehamilan melewati masa 120 hari adalah haram, karena pada saat itu janin telah bernyawa. Dasar dari hukum ini adalah hadits pertama sebagaimana yang telah dijelaskan. Karena pada usia tersebut janin telah bernyawa, maka menggugurkannya sama dengan membunuh manusia (anak) yang secara jelas diharamkan oleh Allah SWT, seperti yang tertera dalam Q.S. al-An'am : 151, Q.S. al-Isra' : 33, dan sebagainya.

Aborsi pada usia di atas 120 hari hanya boleh dilakukan jika terjadi kondisi "dharurat" seperti ketika si ibu mengalami problem persalinan dan dokter spesialis menyatakan bahwa mempertahankan kehamilan akan membahayakan jiwa si ibu. Dalam kondisi seperti ini menyelamatkan jiwa si ibu dinilai lebih penting dari mempertahankan janin, karena ibu adalah induk dari mana janin berasal. Sedangkan aborsi pada usia kehamilan di bawah 40 hari hukumnya makruh. Inipun dengan syarat adanya keridhaan dari suami dan istri serta adanya rekomendasi dari dua orang dokter spesialis bahwa aborsi itu tidak menyebabkan kemudharatan bagi si ibu.

Imam al-Ghazali (1983) dalam kitabnya Ihya 'Ulum al-Din, berpendapat bahwa aborsi adalah tindakan pidana yang haram tanpa melihat apakah sudah ada ruh atau belum. Al-Ghazali mengatakan bahwa kehidupan telah dimulai sejak pertemuan antara air sperma dengan ovum di dalam rahim perempuan. Jika telah ditiupkan ruh kepada janin, maka itu merupakan tindak pidana yang sangat keji, setingkat dengan pembunuhan bayi hidup-hidup.

Diantara alasan yang sering dikemukakan fuqaha (ahli hukum) untuk membolehkan aborsi adalah keringnya air susu ibu yang disebabkan kehamilan, sementara ia sendiri sedang menyusui bayinya. Dalam keadaan demikian ia atau suaminya tidak mampu membayar air susu yang lain. Alasan lain adalah ketidakmampuan ibu menanggung beban hamil, karena tubuhnya yang kurus dan rapuh. Dalam kasus-kasus seperti ini aborsi tanpa memandang usia kehamilan, dapat dilakukan sepanjang menurut penelitian medis yang dapat dipercaya, kelahirannya dipastikan akan membahayakan jiwa ibu.

Dilema kematian antara ibu dan janin dalam pandangan fuqaha dipecahkan melalui pengorbanan janin berdasarkan kaedah: 
"Jika terjadi pergulatan antara dua hal yang sama-sama merugikan, maka yang harus dipertahankan adalah hal yang menimbulkan kerugian paling berat dengan mengorbankan kerugian yang lebih ringan”.

Dalam pandangan fuqaha, kematian ibu lebih berat daripada janin, karena ibu adalah induk darimana janin berasal. Ia sudah memiliki eksistensi yang pasti, memiliki kewajiban dan hak, sementara janin belum. Karena itu ia tidak boleh dikorbankan demi menyelamatkan janin yang eksistensinya belum pasti dan belum memiliki kewajiban (Husain Muhammad, 2001).

Seks bebas yang mengakibatkan terjadinya kehamilan di luar nikah, baik melakui perzinaan maupun pemerkosaan tidak terlalu menarik perhatian fuqaha klasik- ternyata menarik perhatian tersendiri bagi fuqaha kontemporer. Sa'id Ramadhan al-Buthi dengan tegas mengatakan bahwa aborsi untuk kasus yang demikian adalah haram mutlak. Ia mengemukakan Hadits Nabi sebagai berikut:

Hadits mengenai perempuan Ghamidiyah yang diriwayatkan Muslim dari Buraidah ra. yang datang kepada Rasulullah dengan membawa pengakuan ia telah berzina dengan Ma'iz bin Malik dan sedang hamil karenanya. Ma'iz dirajam lebih dulu setelah empat kali membuat pengakuan zina dan meminta Rasulullah mensucikannya. Namun terhadap perempuan Ghamidiyah itu Rasul menangguhkan hukuman rajam sampai ia melahirkan anaknya dan menyapihnya. Setelah si anak disapih dan diserahkan kepada orang lain, barulah ia dirajam. (HR. Muslim)

Hadits ini menunjukkan bahwa anak yang dikandung akibat zina tidak boleh digugurkan. Bahkan Imam Nawawi dalam syarah atas hadits ini menyatakan bahwa semua had, termasuk hukuman jilid, harus ditangguhkan ketika perempuan sedang hamil demi menjaga kehidupan janin.

Juga adanya kaedah fiqhiyah yang menyatakan "tasharruf al-imam 'ala al-ra'iyah manuthun bi al-maslahah”. Berdasarkan kaedah ini ibu dari si bayi tidak boleh menggugurkan kandungannya, karena ia secara syar'i tidak berhak atas janin tersebut. Berbeda dengan aborsi dalam perkawinan di mana kedua orang tua punya hak atas janin, aborsi karena perzinaan tidak demikian. Si ibu tidak memiliki hak syar'i atas anaknya, demikian pula lelaki yang menghamilinya. Hak perwalian ada di tangan hakim, sementara hakim harus 
mengambil tindakan yang melindungi hak janin yang ada dalam perwaliannya sekaligus hak-hak masyarakat. Oleh karena itu aborsi tidak diperbolehkan karena akan membawa dampak negatif bagi masyarakat secara luas, yakni dengan munculnya sikap permisif terhadap pergaulan bebas.

Dengan demikian aborsi akibat perzinahan dipandang oleh fiqh kontemporer sebagai tindak kriminal yang berkaitan erat dengan moralitas sosial (jarimah ijtima'iyah). Pengecualian hanya berlaku jika si perempuan diancam dibunuh jika tidak melakukan aborsi. Dalam kasus seperti ini aborsi diperbolehkan karena untuk menyelamatkan jiwa si ibu.

\section{Kesimpulan}

Aborsi bukan sekedar masalah medis atau kesehatan masyarakat, namun juga merupakan problem sosial yang muncul karena manusia mengekor pada peradaban barat. Solusinya adalah harus dilakukan secara komprehensif-fundamental-radikal, artinya dengan mencabut sikap taqlid kepada peradaban barat dengan menghancurkan segala nilai dan institusi peradaban barat yang bertentangan dengan Islam, untuk kemudian digantikan dengan peradaban Islam yang manusiawi dan adil.

Seluruh ulama dari semua madzhab sepakat bahwa aborsi setelah kehamilan melewati masa 120 hari adalah haram, karena pada saat itu janin telah bernyawa. Aborsi pada usia di atas 120 hari hanya boleh dilakukan jika terjadi kondisi "dharurat" seperti ketika si ibu mengalami problem persalinan dan dokter spesialis menyatakan bahwa mempertahankan kehamilan akan membahayakan jiwa si ibu. Dalam kondisi seperti ini menyelamatkan jiwa si ibu dinilai lebih penting dari mempertahankan janin, karena ibu adalah induk dari mana janin berasal. Sedangkan aborsi pada usia kehamilan di bawah 40 hari hukumnya makruh. Inipun dengan syarat adanya keridhaan dari suami dan istri serta adanya rekomendasi dari dua orang dokter spesialis bahwa aborsi itu tidak menyebabkan kemudharatan bagi si ibu. 


\section{Daftar Pustaka}

Adrina dkk, Hak-Hak Reproduksi Perempuan yang Terpasung, Jakarta: Pustaka Sinar Harapan, 1998

al-Ghazali, al-Imam, Ihya 'Ulum al-Din, Juz II, Beirut: Dar al-Ma'rifah, 1983

an-Nawawi, al-Imam, Syarah an-Nawawi 'ala Sahih Muslim, Juz XI

Hasyim, Syafiq, Menakar Harga Perempuan, Bandung: Mizan, 1999

Depag RI, Al-Qur'an dan terjamahannya

Hasan, M. Ali, Masail Fiqhiyah al-Haditsah pada Masalah-Masalah Kontemporer Hukum Islam, Jakarta: Raja Grafindo Persada, 1998

Harkrisnowo, Harkristuti, "Aborsi ditinjau dari Perspektif Hukum", Makalah, Jakarta: PPFNU, 2000

Kompas, tanggal 30/11/2007

Majalah Gemari September 2006

Muslim, Sahih Muslim, Juz II, Beirut: Dar al-Fikr, 1992

Muhammad, Husein, “Aborsi dalam Perspektif Fiqh Kontemporer", Makalah, Jakarta:, 2001

Pusat Pembinaan dan Pengembangan Bahasa Indonesia Depdikbud RI, Kamus Besar Bahasa Indonesia, Jakarta: Balai Pustaka, 1995, Cet. ke-2

Zuhdi, Masyfuk, Masail Fiqhiyah Kapita Selekta Hukum Islam, Jakarta: CV. Haji Masagung, 1989, Cet. ke-3

www.womenonweb.org, tanggal 26 Oktober 2011

www.genesis2000, tanggal 5 Nopember 2011 